\title{
The return of the RSV
}

Fernando Ferrero $^{1}$, Maria Ossorio ${ }^{1}$, and Maria Rial ${ }^{1}$

${ }^{1}$ Hospital General de Niños Pedro de Elizalde

December 22, 2021

\begin{abstract}
Respiratory syncytial virus (RSV) hospitalizations disappeared in 2020. Now, with southern hemisphere 2021 winter behind us, RSV has returned. Despite it is difficult to weigh the impact of pandemic mitigation measures on common respiratory virus circulation, it appears that acute respiratory infections in children are returning to their usual epidemiology.
\end{abstract}

\section{Hosted file}

VSRvsCOVID_main02dec2021.docx available at https://authorea.com/users/332096/articles/548122the-return-of-the-rsv

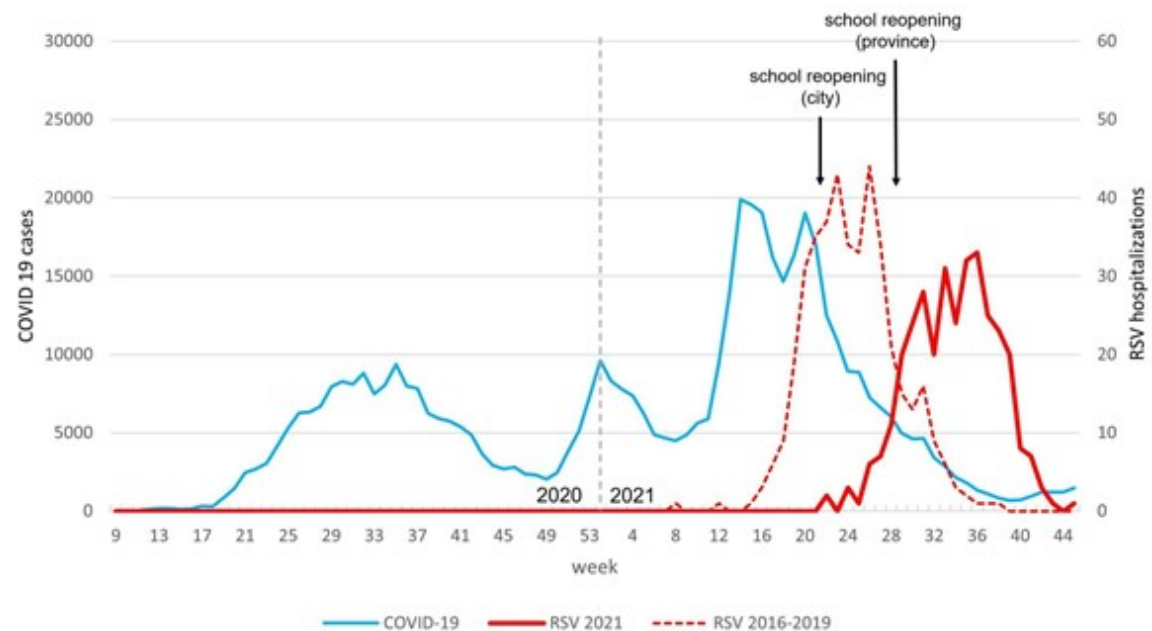

